Abstracta Iranica Abstranica

Revue bibliographique pour le domaine irano-aryen

Volume 32-33 | 2013

Comptes rendus des publications de 2009-2010

\title{
Caroline Waerzeggers. Babylonians in Susa. The Travels of Babylonian Businessmen to Susa Reconsidered
}

\section{Astrid Nunn}

\section{(2) OpenEdition}

1 Journals

Édition électronique

URL : http://journals.openedition.org/abstractairanica/40437

DOI : 10.4000/abstractairanica.40437

ISSN : 1961-960X

\section{Éditeur :}

CNRS (UMR 7528 Mondes iraniens et indiens), Éditions de l'IFRI

\section{Édition imprimée}

Date de publication : 1 décembre 2013

ISSN : 0240-8910

\section{Référence électronique}

Astrid Nunn, « Caroline Waerzeggers. Babylonians in Susa. The Travels of Babylonian Businessmen to Susa Reconsidered », Abstracta Iranica [En ligne], Volume 32-33 | 2013, document 129, mis en ligne le 01 juillet 2016, consulté le 28 septembre 2020. URL : http://journals.openedition.org/abstractairanica/ 40437 ; DOI : https://doi.org/10.4000/abstractairanica.40437

Ce document a été généré automatiquement le 28 septembre 2020.

Tous droits réservés 


\title{
Caroline Waerzeggers. Babylonians in Susa. The Travels of Babylonian Businessmen to Susa Reconsidered
}

\author{
Astrid Nunn
}

\section{RÉFÉRENCE}

Caroline Waerzeggers. « Babylonians in Susa. The Travels of Babylonian Businessmen to Susa Reconsidered », in : Bruno Jacobs, Robert Rollinger, éds., « Der Achämenidenhof / The Achaemenid Court ». Akten des 2. Internationalen Quolloquiums zum Thema «Vorderasien im Spannungsfeld klassischer und altorientalischer Überlieferungen ", Landgut Castelen bei Basel, 23.-25. Mai 2007. Wiesbaden, 2010, p. 777-813. (Classica et Orientalia(CLeO), 2)

D'après les archives en cunéiforme, les Babyloniens voyageaient régulièrement à Suse (Šušan) à partir du règne de Darius I. Mais de quelle ville de Suse s'agit-il ? (cf. Abs. Ir. 27, 2004, c.r. $n^{\circ}$ 54). Après avoir repris les différentes hypothèses et en avoir fait une longue tabelle, l'A. opte définitivement pour le Suse élamite. Outre les évidences philologiques, le temps des voyages, l'indication des distances, les voyageurs, la raison économique des voyages, tout plaide en faveur de cette interprétation.

\section{AUTEURS}

\section{ASTRID NUNN}

Université de Munich 